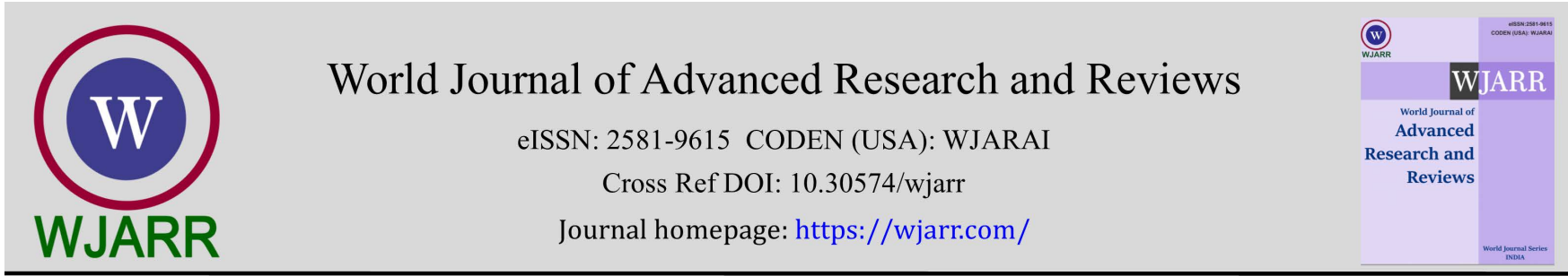

(RESEARCH ARTicle)

Check for updates

\title{
The role of molecular taxonomy in uncovering local ornamental Palo Fish (Betta sp.: Osphronemidae) and other Betta based on Cytochrome b gene
}

\author{
Ummi Kurnia Putri, Rini Simanjuntak, Thoriq Alfath Febriamansyah, Dewi Imelda Roesma *and Djong Hon \\ Tjong
}

Department of Biology, Faculty of Mathematics and Natural Sciences, Andalas University, Jl. Limau Manis, Padang, West Sumatra, Indonesia.

World Journal of Advanced Research and Reviews, 2021, 10(01), 030-040

Publication history: Received on 27 February 2021; revised on 28 March 2021; accepted on 31 March 2021

Article DOI: https://doi.org/10.30574/wjarr.2021.10.1.0113

\begin{abstract}
Cytochrome b gene mitochondrial DNA was used to study the Palo fish from Bukit Rangkak tributary, Harau Valley, West Sumatra. The study aimed to determine the taxonomy of Palo fish, which morphological suspected as the Betta group. Phylogenetic analysis was used to solve the relationship of Palo fish with other species of the Betta. The alignment of the DNA sequences was carried out with Clustal X version 2 and analysis of phylogenetic tree using MEGA 6 software program. Based on the analysis of the cytochrome b gene sequence (1047 bp), it is known that the genetic differences of Palo fish from two tributaries of Bukit Rangkak river is $0.0 \%$ and with other Betta fish ranges from 13.0-35.5\%. The phylogenetic tree has shown that Palo fish has a close genetic relationship with the Betta picta (13.0\%). The result showed that Palo fish is at the different species in the genus of Betta and proposed as a new species.
\end{abstract}

Keywords: Betta fish; Cytochrome b; Harau Valley; Palo fish; Phylogenetic

\section{Introduction}

In general, Betta is a tiny fish with a total length of 2.5-12.5 cm [1]. Betta fish has a finite habitat in lowland freshwater and some exist in Asia's highlands [2]. Betta has a unique color and the shape of the fins and as one of the export commodities as an ornamental fish. $[3,4,5]$. The ornamental fish in their original habitat, especially in the tropics area, has decreased in population because of over-exploitation, deforestation, forest conversion, and water pollution [6, 7, 8].

Some of the Betta species currently can be grouped into complex species and need studies for conservation purposes [9]. The IUCN Red List has classified some of the species in genus Betta as the endangered species; meanwhile, the group's information is limited [10]. Betta fish's grouping for a long time is based on the morphological characters [11, $12,13,14]$. With the development of technology and the use of DNA, currently has developed a systematic study using molecular data, or a combination of both $[15,16,17,18,19,20,21,22,23,24,25]$.

The taxonomic and systematic study of the endangered species is still limited and needs revision to get the information used as the base of the consideration of fish conservation [5]. Fish classifications are being transformed drastically with the development of molecular phylogenetic analysis. Several systematic studies that use molecular phylogenetic analysis have been carried out [26, 27, 28, 29, 30, 31, 32]. Several studies regarding phylogenetic analysis for the Sumatra fish have been reported [34, 35, 36, 37]. Based on the literature, it can be understood that the combination of morphological and molecular analysis provides more information in taxonomic and systematic studies.

\footnotetext{
${ }^{*}$ Corresponding author: Dewi Imelda Roesma

Department of Biology, Faculty of Mathematics and Natural Sciences, Andalas University.Jl. Limau Manis, Padang, West Sumatra, Indonesia.
}

Copyright (@ 2021 Author(s) retain the copyright of this article. This article is published under the terms of the Creative Commons Attribution Liscense 4.0. 
One of the genes that can be used in the phylogenetic analysis is cytochrome $b$. The cytochrome b gene has been widely used in systematic problems at the family to species level [15, 38, 39, 40,41,42,43]. The cytochrome bene is one of the mitochondrial DNA protein-coding genes [44]. Phylogenetic analysis is a grouping of taxa that illustrated the relationship among them. Brown [45] interpreted that phylogenetic is a organism classification method by showing its relationship between them. Weiss and Goker [46] state that the phylogenetic hypothesis can be described in a tree form, composed of branches that representing the relationship between them and the node as a species.

There are 79 known species in the genus of Betta [9]. One of them is found in the highlands of Sumatra island (Indonesia) in Harau Valley, which is part of the Bukit Barisan mountain range in West Sumatra. The local people named it Palo fish. Palo fish has an attractive color on the operculum, and it has small-sized with an average of $66.9 \mathrm{~mm}$ total length and $11.38 \mathrm{~mm}$ body width. The morphological appearance strengthens the suspicion that Palo was Betta fish

The limit of genetic information on Palo fish makes it difficult in the taxonomic grouping. The studies are needed regarding the genetic relationship between Palo fish and other Betta species using the cytochrome b gene in phylogenetic analysis. The phylogenetic information can later be used in determining the systematic and management of conservation of Palo fish in the Bukit Rangkak tributary.

\section{Material and methods}

\subsection{Study area}

Samples were collected from two Bukit Rangkak tributary locations, Harau Valley, West Sumatra (Figure. 1) using survey methods, direct collection [47]. The sample was fixed with $4 \%$ formalin for several days and transferred to $70 \%$ alcohol for long-term preservation. The tissue samples of Palo fish were stored in a microtube (1.5 ml) filled with $96 \%$ ethanol PA as a DNA resource.

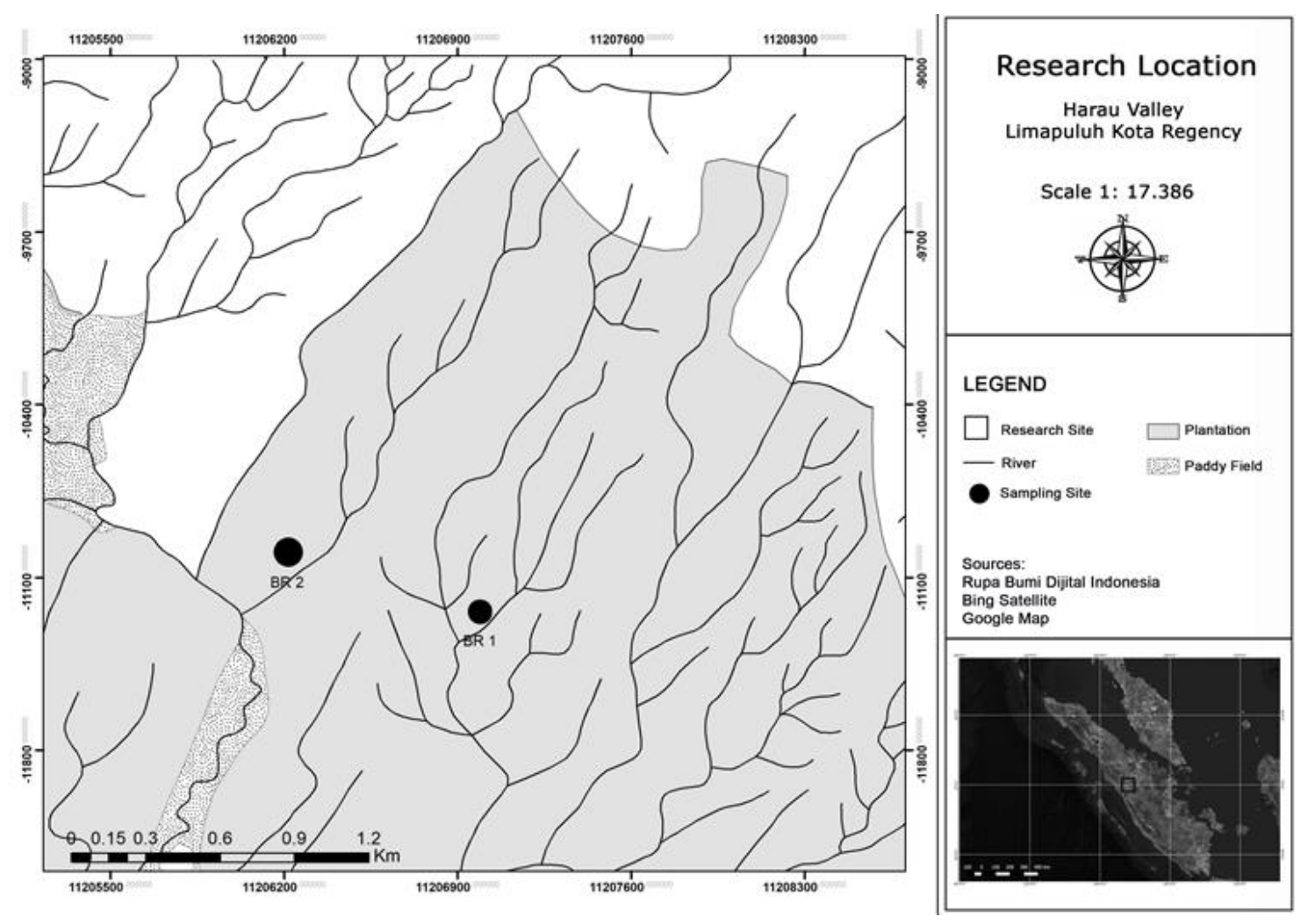

Figure 1 Research Location Map 


\subsection{Procedures}

DNA isolation was done based on the PureLinkTM Genomic DNA Kit protocol INVITROGEN Kit. PCR amplification was done using the reaction of a mixture with a total volume of $25 \mu \mathrm{l}$, consisting of $12.5 \mu \mathrm{l}$ Gotaq green, $3.5 \mu \mathrm{lddH} 20$, two $\mu \mathrm{l}$ each primer and five $\mu \mathrm{l}$ DNA template. The primers for amplification referred to as DonGlu F and DonThr R [15].

PCR was carried out for 35 cycles. The PCR process starts initial denaturation at $94^{\circ} \mathrm{C}$ for $2 \mathrm{~min}$, followed by denaturation at $94^{\circ} \mathrm{C}$ for $60 \mathrm{~s}$, annealing at $51^{\circ} \mathrm{C}$ for $60 \mathrm{~s}$, and $72^{\circ} \mathrm{C}$ for $90 \mathrm{~s}$ for elongation. The final extension phase at $72^{\circ} \mathrm{C}$ for $5 \mathrm{~min}$. The quality of the PCR product examined the $2 \%$ agarose gel electrophoresis. The PCR product was sent for sequencing at the $1^{\text {st }}$ Base Malaysia.

\subsection{Data Analysis}

The DNA sequence of Palo fish arranged by forward and reverse contig with DNA STAR program [48] to get the DNA sequence. Compared with the 33 accessions of cytochrome b gene sequences from Osphronemidae, Cyprinidae, and Pomancetridae family, the DNA sequence of Palo fish, was download from GenBank NCBI (National Center of Biotechnology Information). The alignment of the DNA sequence used Clustal X 1.8 version and edited by Bioedit. The polymorphism sequence analyses used DNA sequence polymorphism 5.10. [49]. The phylogenetic tree was constructed and analyzed by MEGA (Molecular Evolutionary Genetics Analysis) 6 [50].

\section{Results and discussion}

\subsection{Result}

\subsubsection{Blast Analysis}

The BLAST analysis results were used to determine the similarity value of the Palo fish sequences with their close relatives. In the present study, eight cytochrome b mitochondrial DNA sequences of Palo fish were used. The BLAST results showed that the similarity value of Palo fish with the Betta genus was 88-99\% (Table 1). Palo fish sequences have the highest similarity value to Betta picta species (99\%).

Based on BLAST results, 33 cytochrome b gene sequences were downloaded from NCBI GenBank as a comparison. The downloaded sequences consist of species from the family of Osphronemidae and two species from the family Cyprinidae and Pomacentridae. The total of all sequences that were analyzed included sequences Palo fish are 41 sequences.

The number of nucleotide bases resulting from the alignment of all sequences analyzed was $1047 \mathrm{bp}$, which in the position of 14468-15500 bp of Betta pi complete genome. Prakhongcheep et al. [24] reported that the Betta pi cytochrome $b$ gene sequence at the full genome site at the range from 14388-15543 bp. From $1047 \mathrm{bp}$ sequences, 470 bp (44.89\%) as conserved site, $577 \mathrm{bp}(55.10 \%)$ as variable site, $498 \mathrm{bp}(47.56 \%)$ as parsimony site and $79 \mathrm{bp}(7.54 \%)$ as a singleton site.

The nucleotide base compositions of $1047 \mathrm{bp}$ cytochrome b gene are A (Adenine) 25.9\%, T (Thymine) 30.6\%, C (Cytosine) 28.8\%, and G (Guanin) 14.7\%. The average percentage of Adenine+Thymine (A+T) nucleotide base was $56.5 \%$, and Guanin+Cytosine $(\mathrm{G}+\mathrm{C})$ nucleotide bases were $43.5 \%$. The number of bases in Palo fish $(\mathrm{A}+\mathrm{T})$ is higher than $(\mathrm{G}+\mathrm{C})$. According to the previous researchers $[51,52,53,54,55]$ the number of bases $(A+T)$ in vertebrates is higher than $(\mathrm{G}+\mathrm{C})$.

Based on the polymorphism sequence analysis using the DNA Sequence Polymorphism program [51] 34 haplotypes were obtained from the 41 sequences analyzed (Table 2). Eight individuals Palo fish from two tributary locations, belonging to the same haplotype, namely Haplotype 1 . Based on the haplotype analysis results, it can be stated that there is no genetic variation in the two Palo fish populations. Geographically, two tributaries of sampling sites are from the same upstream. 
Table 1 Species List taxonomy, Location and Genbank Accession Number of samples.

\begin{tabular}{|c|c|c|c|c|c|}
\hline No & Family & Genus & Species & $\begin{array}{l}\text { Accession } \\
\text { Numbers }\end{array}$ & Location \\
\hline 1 & \multirow{31}{*}{ Osphronemidae } & \multirow{25}{*}{ Betta } & Betta breviobesus & AF519668.1 & Indonesia \\
\hline 2 & & & Betta pi & AF519672.1 & Thailand \\
\hline 3 & & & Betta waseri & AF519671.1 & Sumatra \\
\hline 4 & & & Betta hipposideros & AF519673.1 & Selangor \\
\hline 5 & & & Betta chloropharynx & AF519675.1 & Banka \\
\hline 6 & & & Betta anabatoides & AF519674.1 & Borneo \\
\hline 7 & & & Betta edithae & AF519663.1 & Borneo \\
\hline 8 & & & Betta prima & AF519664.1 & Thailand \\
\hline 9 & & & Betta imbellis & AF519690.1 & Sumatra \\
\hline 10 & & & Betta splendens & AF519689.1 & Mekong \\
\hline 11 & & & Betta smaragdina & AF519688.1 & Mekong \\
\hline 12 & & & Betta rutilans & AF519682.1 & Borneo \\
\hline 13 & & & Betta brownorum & AF519681.1 & Borneo \\
\hline 14 & & & Betta cf. burdigala & AF519678.1 & Banka \\
\hline 15 & & & Betta tussyae & AF519679.1 & Malaysia \\
\hline 16 & & & Betta coccina & AF519684.1 & Borneo \\
\hline 17 & & & Betta pugnax & AF519665.1 & Singapore \\
\hline 18 & & & Betta fusca & AF519666.1 & Sumatra \\
\hline 19 & & & Betta dimidiate & AF519667.1 & Borneo \\
\hline 20 & & & Betta picta & AF519670.1 & Malaya \\
\hline 21 & & & Betta simplex & AF519669.1 & Thailand \\
\hline 22 & & & Betta cf. albimarginata & AF519676.1 & Borneo \\
\hline 23 & & & Betta ocellata & AF519693.1 & Borneo \\
\hline 24 & & & Betta patoti & AF519691.1 & Borneo \\
\hline 25 & & & Betta unimaculata & AF519692.1 & Borneo \\
\hline 26 & & \multirow{2}{*}{ Trichogaster } & Trichogaster pectoralis & AY763758.1 & Borneo \\
\hline 27 & & & Trichogaster trichopterus & AY763759.1 & Thailand \\
\hline 28 & & \multirow{2}{*}{ Pseudosphromenus } & Pseudosphromenus dayi & AY763764.1 & India \\
\hline 29 & & & Pseudosphromenus cupanus & AF519699.1 & Srilanka \\
\hline 30 & & \multirow{2}{*}{ Parosphromenus } & Parosphromenus paludicola & AY763763.1 & Malaysia \\
\hline 31 & & & Parosphromenus anjunganensis & AY763761.1 & Borneo \\
\hline 32 & Cyprinidae & Cyprinus & Cyprinus carpio & AY347294.1 & India \\
\hline 33 & Pomacetridae & Chrysiptera & Chrysiptera traceyi & JQ707176.1 & West Pacific \\
\hline
\end{tabular}


Table 2 Haplotypes of Palo fish and other species

\begin{tabular}{|c|c|c|}
\hline No & Haplotype & Species \\
\hline 1 & Haplotype 1 & Palo \\
\hline 2 & Haplotype 2 & Betta breviobesus \\
\hline 3 & Haplotype 3 & Betta pi \\
\hline 4 & Haplotype 4 & Betta waseri \\
\hline 5 & Haplotype 5 & Betta hipposideros \\
\hline 6 & Haplotype 6 & Betta chloropharynx \\
\hline 7 & Haplotype 7 & Betta anabatoides \\
\hline 8 & Haplotype 8 & Betta edithae \\
\hline 9 & Haplotype 9 & Betta prima \\
\hline 10 & Haplotype 10 & Betta imbellis \\
\hline 11 & Haplotype 11 & Betta splendens \\
\hline 12 & Haplotype 12 & Betta smaragdina \\
\hline 13 & Haplotype 13 & Betta rutilanss \\
\hline 14 & Haplotype 14 & Betta brownorum \\
\hline 15 & Haplotype 15 & Betta cf. Burdigala \\
\hline 16 & Haplotype 16 & Betta tussyae \\
\hline 17 & Haplotype 17 & Betta coccina \\
\hline 18 & Haplotype 18 & Betta pugnax \\
\hline 19 & Haplotype 19 & Betta fusca \\
\hline 20 & Haplotype 20 & Betta dimidiate \\
\hline 21 & Haplotype 21 & Betta picta \\
\hline 22 & Haplotype 22 & Betta simplex \\
\hline 23 & Haplotype 23 & Betta cf. Albimarginata \\
\hline 24 & Haplotype 24 & Betta ocellata \\
\hline 25 & Haplotype 25 & Betta patoti \\
\hline 26 & Haplotype 26 & Betta unimaculata \\
\hline 27 & Haplotype 27 & Cyprinus carpio \\
\hline 28 & Haplotype 28 & Chrysiptera traceyi \\
\hline 29 & Haplotype 29 & Trichogaster pectoralis \\
\hline 30 & Haplotype30 & Trichogaster trichopterus \\
\hline 31 & Haplotype 31 & Pseudosphromenus dayi \\
\hline 32 & Haplotype 32 & Pseudosphromenus cupanus \\
\hline 33 & Haplotype 33 & Parosphromenus paludicola \\
\hline 34 & Haplotype 34 & Parosphromenus anjunganensis \\
\hline
\end{tabular}

\subsection{Phylogenetic Analysis}

The phylogenetic tree constructed by cytochrome b gene (Figure 2) separated into four main clusters based on genus with sequence divergences 13.0-50.0\%. The first cluster was placed by species from the Betta genus with sequence divergences $13.0-35.5 \%$. The second cluster placed by two species from the Pseudosphromenus genus with sequence divergences $32.7-42.9 \%$ to the first cluster. The third cluster was placed by two species from the Parosphromenus genus with sequence divergences $35.1-50.0 \%$ to the first and second clusters. The fourth cluster was placed by two species from the Trichogaster genus with sequence divergences $31.1-40.9 \%$ to the other three clusters. 
The first cluster consists of 26 species of the Betta genus, divided into two sub-clusters. The first sub-cluster consists of 23 species with sequence divergences 13.0-20.4\%, and the second sub-cluster consists of 3 species with a sequence of 29.4-46.5\% to the first sub-cluster. Based on the sequence divergences, the first cluster is divided into four groups, namely the pugnax, albimarginata, coccina, and unimaculata. The lower the sequence divergences value, the closer the position in the phylogenetic tree and vice versa. According to Kartavtsev et al. [43] and Kartavtsev et al. [56] the sequence divergences value of a species will increase with the taxon's increasing level. This separating group is in line with another result [15] who divided the Betta genus into seven groups, pugnax, albimarginata, coccina, foerschi, splendens, unimaculata, and macrostoma. Morphological differences were also detected in these four groups by looking at a sketch from Ruber et al. [15] used in phylogenetic trees (Figure 2). The illustration shows the different characteristics of the caudal fin shape of each group. The pugnax group has lancet-shaped caudal fins; the coccina group is perfectly rounded while the albimarginata and unimaculata caudal fins are rounded modified with a flat caudal tip. Differences in morphological characters in the four groups are also explained by Tan and $\mathrm{Ng}$ [11]. The pugnax group has characteristics of lancet-shaped on caudal fins. The albimarginata group has wide and falcate pelvic fins, rounded caudal fins. The coccina groups are identical with small body sizes, and the unimaculata group has pelvic, dorsal, tapered fins and lancet-shaped caudal fins.

\section{Discussion}

Palo fish are in the first group (pugnax group) and B. picta, B. simplex, B. breviobesus, B. anabatoides, B. chloropharynx, B. hipposideros, B. pi, B. waseri, B. dimidiate, B. pugnax, B. fusca, B. edithae, B. prima. The value of the sequence divergences in this sub-cluster is $13.0 \%-20.8 \%$. Based on the Authors $[43,56]$ that value, has grouped the species in this group into the same genus. Therefore, Palo fish is one of the species of the genus Betta. Ruber et al. [15] supported the grouped of B. picta, B. simplex, B. breviobesus, B. anabatoides, B. chloropharynx, B. hipposideros, B. pi, B. waseri, B dimidiate, B. pugnax, $B$. fusca, B. edithae, B. prima in the same cluster, the pugnax group. This grouping is also supported by morphological forms that are similar to each other. Tan and $\mathrm{Ng}$ [11] describe that the Betta pugnax group has the characteristics. They have a black line chin bar from under the eye to the lower jaw, there are transverse bars in the form of black transverse stripes on the dorsal, anal and caudal fins in adult male individuals and have caudal fins lancet-shaped. These characteristics are also found in Palo fish (Figure 3). This explanation confirms that the Palo fish is a species of the Betta genus which belongs to the pugnax group.

In the second group, the albimarginata group is consists of Betta cf. albimarginata, with 28.0\%. Sequence divergences to Palo fish. Referring to Kartavtsev et al. [43] and Kartavtsev et al. [56] Palo fish is a different species in the same genus as Betta cf. albimarginata. Ruber et al. [15] also show that Betta cf. Albimarginata forms a separate group, the albimarginata group.

The coccina group is in the third group consist of B. coccina, B. tussyae, B. cf. burdigala, B. rutilanss, and B. brownorum. These species are found in Indonesia, Thailand, and Malaysia. The sequence divergences between Palo fish and these species ranges from 28.7-33.1\%. Following Kartavtsev et al. [43] and Kartavtsev et al. [56] it was concluded that Palo fish is a species of a different family from other species in the coccina group.

The fourth group ist the unimaculata group consisting of B. unimaculata, B. ocellata, and B. patoti. These species are Betta fish found in East Kalimantan. The sequence divergences between Palo fish and these species ranges from 27.328.3\%. Referring to Kartavtsev et al. [43] and Kartavtsev et al. [56] means that Palo fish are a different species in other families of the unimaculata group.

The phylogenetic tree also shows that B. picta is the closest branch of the Palo fish, with a $13.0 \%$ sequence divergences. Based on Kartavtsev et al. [43] and Kartavtsev et al. [56] Palo fish are a different species of B. picta. The difference in the distribution of these two species supports the high level of genetic variation. B. picta has a distribution area on the island of Java [11]. Meanwhile, Palo fish was found in the tributaries of Bukit Rangkak, West Sumatra. Ruber et al. [15] grouping the B. picta into the pugnax group based on nuclear and mitochondrial DNA analysis and the evolutionary history of parenting mouthboarding in the Betta genus.

On the other hand, Tan and $\mathrm{Ng}$ [11] did not include the B. picta into the pugnax group; rather, it has its group, the picta group (based on morphometric and meristic characters, with striking differences in the anal and caudal fin patterns). Witte and Schmit [57] have described B. picta as having a rounded caudal fin pattern and the anal fin sometimes tapered. This character difference is also seen in Palo fish, which have lancet caudal fin patterns and tapered anal fins, which are the pugnax group's characters. However, based on the analysis of the cytochrome b gene, it can be stated that the $B$. picta is a sister taxon of the Palo fish because it has the closest genetic distance compared to other Betta species used in 
this analysis. In line with the opinion of Gregory's opinion [55] which states that sister taxa are a close relative of a species that comes from the same branch in a phylogenetic tree.

Based on cytochrome $b$ gene analysis, it is also known that there is no genetic variation between Palo fish populations from two locations of the Bukit Rangkak tributaries with a sequence divergences of $0.0 \%$. That value is presumably due to the two sites of tributaries, which are branches of the Bukit Rangkak tributary (Figure 1). The possibility of interpopulation breeding still occurs. This possibility is supported by Roesma et al. [35] which states that if genetic mixing between species with separate locations can still occur, then genetic similarities between species are always maintained. In line with the statements of Garg and Mishra [54] which states that gene flow has the potential to reduce genetic differentiation. Zero genetic variation between Palo fish populations based on the cytochrome b gene is also predicted because these two populations come-from the same ancestor. The fragmentation between tributaries does not affect reproductive isolation because two populations come from the same ancestor. Song et al. [59] and Song et al. [60] states that mtDNA's genetic component is inherited maternally and there is no recombination, the genetic variation will arise if there is a separation of common ancestor components due to genetic drift or bottleneck effect.

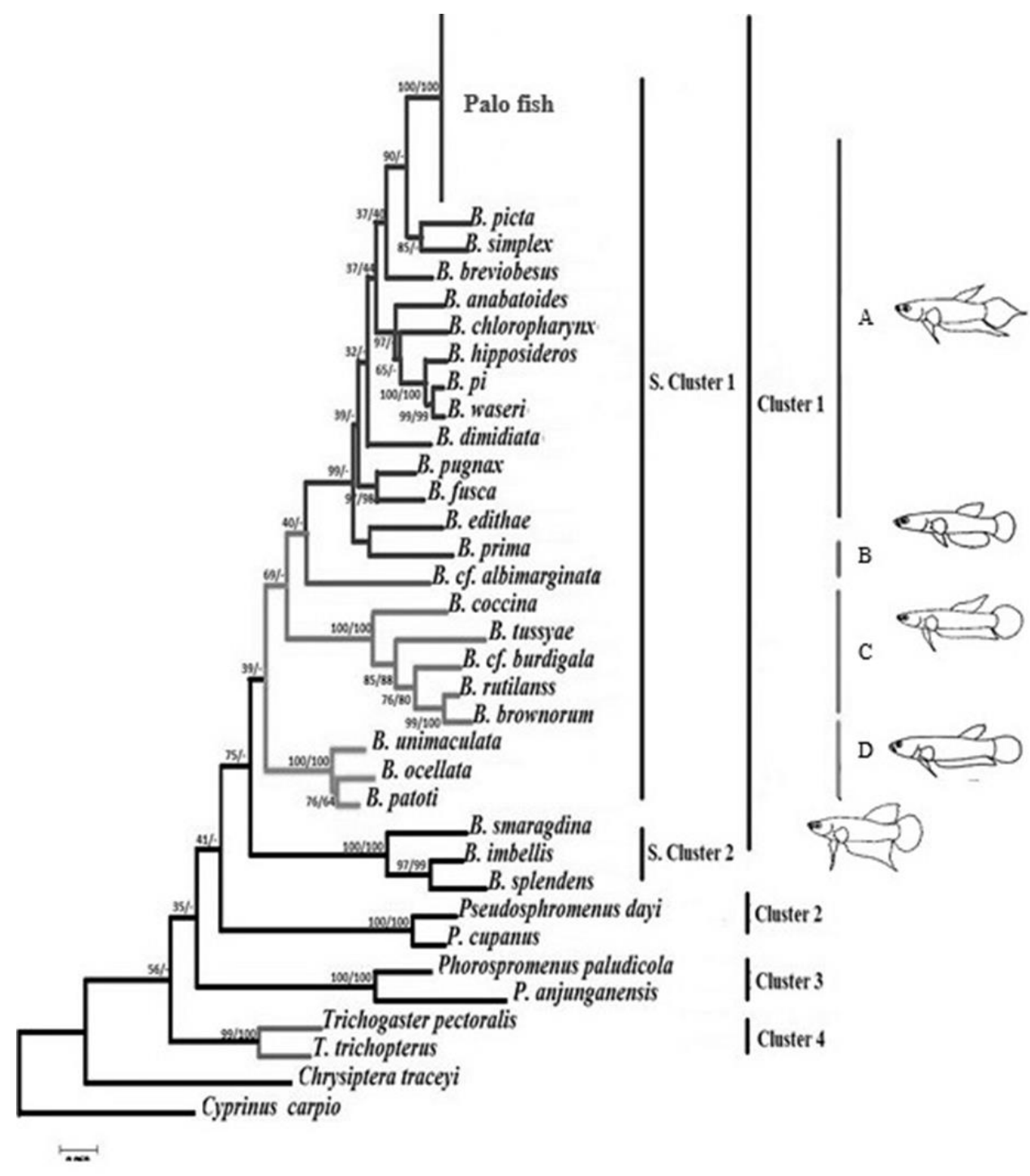

Figure 2 The ML phylogenetic tree of the cytochrome b gene with the bootstrap value of 1000 replicates (ML/NJ). Note: A. pugnax group; B. albimarginata group; $C$. coccina group; $D$. unimaculata group. Sketch of the picture based on Ruber et al. (2004) 


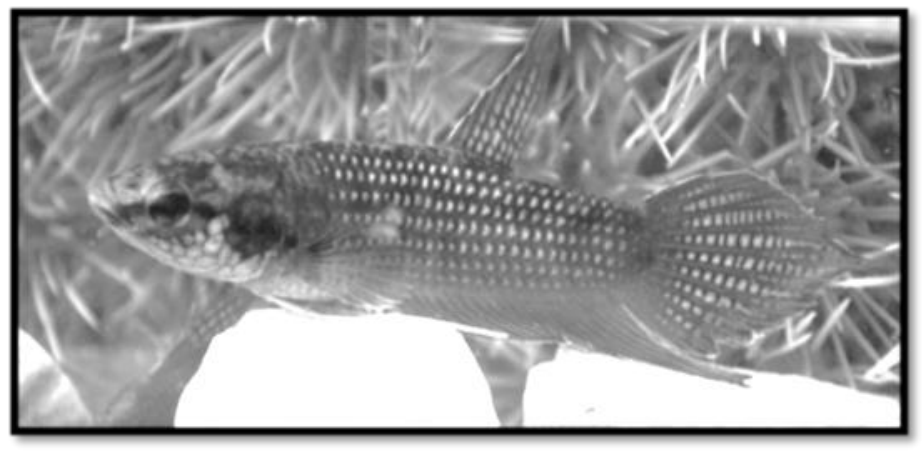

Figure 3 Adult male Palo fish

\section{Conclusion}

The present study reported that Palo fish from two populations of Bukit Rangkak tributaries are genetically identical. Palo fish belong to the genus Betta in the pugnax group. The Palo fish sequence's value is $13.0 \%$ with other Betta genus species; therefore, the present study proposed that the Palo fish is a new species in the Betta genus. Further research is being carried out.

\section{Compliance with ethical standards}

\section{Acknowledgments}

We want to thank the Ministry of Research, Technology, and Higher Education Management to assist PKM-P research grant assistance in 2018. Our thanks also expressed to the Biology Department of Andalas University for the field and Laboratory work permit. We also would like to thank our friends, who helped us in samples collection and laboratory works in Genetic and Biomolecular Laboratory, Faculty of Mathematics and Sciences, Andalas University, Padang, Indonesia.

\section{Disclosure of conflict of interest}

There is no interst in the conflict between the authors of this piece of research work. The authors agreed and assigned in hand to all matter arise to this piece of research work.

\section{References}

[1] Kottelat M, Lim KKP. Freshwater fishes of Sarawak and Brunei Darussalam: a preliminary annotated check-list. Sarawak Museum Journal. 1995; 48 (69): 227-256.

[2] Kottelat M, Whitten AJ, Kartikasari SN, Wiejoatmodjo S. Freshwater Fishes of Western Indonesia and Sulawesi. Periplus Eds. (HK) Ltd., and EMDI: Indonesia, Singapore. 1993.

[3] Ng PKL, Tay JB, Lim BK. Diversity and conservation of blackwater fishes in peninsular Malaysia, particularly in the North Selangor peat swamp forest. Hydrobiologia. 1994; 285: 203-218.

[4] Ng PKL, Tan HH. Freshwater fishes of Southeast Asia: Potential for the aquarium fish trade and conservation issues. Aquar Sci Conserv. 1997; 1: 9-90.

[5] Hubert N, Kadarusman, Wibowo A, Busson F, Caruso D, Sulandari S, Nafiqoh N, Pouyaud L, Ruber L, Avarre JC, Herder F, Hanner R, Keith P, Renny K, Hadiaty. DNA Barcoding Indonesian freshwater fishes: challenges and prospects. DNA Barcodes. 2015; 3: 144-169.

[6] Hansen MC, Stehman SV, Potapov PV, Arunarwati B, Stolle F, Pittman K. Quantifying changes in the rates of forest clearing in Indonesia from 1990 to 2005 using remotely sensed data sets. Environ Res Lett. 2009; 4: 034001.

[7] Giam X, Koh LP, Tan HH, Miettinen J, Tan HTW, Ng PKL. Global extinctions of freshwater fishes follow peatland conversion in Sundaland. Front Ecol Environ. 2012; 10(9): 465-470.

[8] Degani F. Mitochondrial DNA sequence analysis in Anabantoidei fish. Advances in Biological Chemistry. 2013; 3: 347-355. 
[9] Froese R, Pauly D. Fishbase. A global information system on fishes. 2004.

[10] IUCN. Betta. [Online]. 2019.

[11] Tan HH, Ng PKL. The fighting fishes (Teleostei: Osphronemidae: Genus Betta) of Singapore, Malaysia and Brunei. Raffles Bulletin of Zoology Supplement. 2005; 13: 43-99.

[12] Schindler I, Schmidt H. Review of the mouthbrooding Betta (Teleostei Osphronemidae) from Thailand, with descriptions of two new species. Zeitschrift Fiir Fischkunde. 2006; 8: 47-69.

[13] Schindler I, Schmidt J. Betta kuehnei, a new species of fighting fish (Teleostei, Osphronemidae) from the Malay Peninsula. Bulletin of Fish Biology. 2008; 10 (1/2).

[14] Kowasupat C, Panijpan B, Ruenwongsa P, Sriwattanarothai N. Betta mahachaiensis, a new species of bubblenesting fighting fish (Teleostei: Osphronemidae) from Samut Sakhon Province, Thailand. Zootaxa. 2012; 3522: 49-60.

[15] Ruber L, Britz R, Tan HH, Ng PKL, Zardoya R. Evolution of mouthbrooding and life-history correlates in the fighting fish genus Betta. Evolution. 2004; 58: 799-813.

[16] Meejui O, Sukmanomon S, Na-Nakornb U. Allozyme revealed substantial genetic diversity between hatchery stocks of siamese fighting fish, Betta splendens, in the province of Nakornpathom, Thailand. Aquaculture. 2005; 250: 110- 119 .

[17] Kumar S. Genetic profile of Jenu Kuruba, Betta kuruba and soliga tribes of Southern Karnataka and their phylogenetic relationships. The Anthropologist. 2008; 10: 11-20.

[18] Sriwattanarothai N, Steinke D, Ruenwongsa P, Hanner R, Panijpan B. Molecular and morphological evidence supports the species status of the Mahachai fighter Betta sp. Mahachai and reveals new species of Betta from Thailand. J Fish Biol. 2010; 77: 414-424.

[19] Lee PKY, Ng SY, Yong D, Chai XC, Yin WF, Chan KG. Molecular phylogeny characterization of Malaysian fighting fish Betta Pi (Teleostei: Osphronemidae) based on its 18s ribosomal dna sequences. Asia Life Sciences. 2012; 21: 1-8.

[20] Schindler I, Linke H. Betta hendra-a new species of fighting fish (Teleostei: Osphronemidae) from Kalimantan Tengah (Borneo, Indonesia). Vertebrate-zoology. 2013; 63: 35 - 40.

[21] Chailertrit V, Swatdipong A, Peyachoknagul S, Salaenoi J, Srikulnath K. Isolation and characterization of novel microsatellite markers from Siamese fighting fish (Betta splendens, Osphronemidae, Anabantoidei) and their transferability to related species, B. smaragdina and B. imbellis. Gen Mol Res. 2014; 13(3): 7157-7162.

[22] Humaida F, Abinawanto, Kusrini E. Variation of 16S rRNA Mitochondrial DNA Sequences of Five Betta Fish (Betta sp.) Species from Sumatra and Kalimantan. [Skripsi]. Depok. Indonesia Univ. 2014.

[23] Song YN, Xiao GB, Li JT. Complete mitochondrial genome of the Siamese fighting fish (Betta splendens). Mitochondrial DNA. 2015.

[24] Prakhongcheep O, Narongrit S, Surin P, Kornsorn S. Complete mitochondrial genome of mouthbrooding fighting fish (Betta pi) compared with bubble nesting fighting fish (B. splendens). Mitochondrial DNA Part. 2018; B3: 68.

[25] Ponjarat J, Areesirisuk P, Prakhongcheep O, Dokkaew S, Sillapaprayoon S, Muangmai N, Peyachoknagul S, Srikulnath K. Complete mitochondrial genome of two mouthbrooding fighting fishes, Betta apollon and B. simplex (Teleostei: Osphronemidae). Mitochondrial DNA Part. 2019; B4: 672-674.

[26] Dodson JJ, Colombani F, Ng PKL. Phylogeographic structure in mitochondrial DNA of a Southeast Asian freshwater fish, Hemibagrus nemurus (Siluroidei; Bagridae) and Pleistocene sea-level changes on the Sunda shelf. Mol Ecol. 1995; 4: 331-346.

[27] Chen IS, Hsu CH, Hui CF, Shao KT, Miller PJ, Fang LS. Sequence length and variation in the mitochondrial control region of two freshwater Gobi fishes belonging to Rhinogobius (Teleostei: Gobioidei). J Fish Biol. 1998; 53: 179191.

[28] Wang JP, Hsu KC, Chiang TY. Mitochondrial DNA phylogeography of Acrossocheilus paradoxus (Cyprinidae) in Taiwan. Mol Ecol. 2000; 9: 1483-1494.

[29] Hubert N, Hanner RH, Holm E, Mandrak NE, Taylor EB, Burridge M, et al. Identifying Canadian freshwater fishes through DNA barcodes. PLoS One. 2008; 3: e2490. 
[30] Steinke D, Zemlak TS, Hebert PDN. Barcoding Nemo: DNA-based identifications for the ornamental fish trade. PLoS One. 2009; 4: e6300.

[31] Adamson EAS, Hurwood DA, Mather PB. A reappraisal of the evolution of Asian snakehead fishes (Pisces, Channidae) using molecular data from multiple genes and fossil calibration. Mol Phylo Evol. 2010; 56: $707-717$.

[32] Collins RA, Cruickshank RH. The seven deadly sins of DNA barcoding. Mol Ecol Resour. 2013; 13: 969-975.

[33] Imtiaz A, Mohd-Nor SA, Naim DM. Review: Progress and Potential of DNA barcoding for identification of fish species. Biodiversitas. 2017; 18(4): 1394-1405.

[34] Karlina W, Roesma DI, Tjong DH. Phylogenetic study of Puntius cf. binotatus fish from Gunung Tujuh Lake in Sumatera Based on Cytochrome b gene. JEZS. 2016; 4(2): 538-540.

[35] Roesma DI, Tjong DH, Aidil DR. Phylogenetic analysis of Barau and Sasau fish (Hampala: Cyprinidae) from West Sumatra lakes and rivers based on cytochrome-b gene. Proceedings of the 10th National Fish Seminar. Cibinong, 8-9 Mei 2018.

[36] Roesma DI, Tjong DH, Karlina W, Aidil DR. Taxonomy confirmation of Puntius cf. binotatus from Gunung Tujuh Lake, Jambi, Indonesia, based on Cytochrome Oxidase-I (COI) gene. Biodiversitas. 2019; 20: 54-60.

[37] Roesma DI, Tjong DH, Aidil DR. Phylogenetic analysis of transparent Gobies in three Sumatran Lakes, inferred from mitochondrial Cytochrome Oxidase 1 (Co1) gene. Biodiversitas. 2020; 41(1): 43-48.

[38] Ruber L, Britz R, Zardoya R. Molecular phylogenetics and evolutionary diversification of labyrinth fishes (Perciformes: Anabantoidei). Syst Biol. 2006; 55: 374-397.

[39] Aboim MA, Menezes MG, Schlitt D, Rogers AD. Genetic structure and history of populations of the deep-sea fish Helicolenus dactylopterus (Delaroche, 1809) inferred from mtDNA sequence analysis. Mol Ecol. 2005; 14: 13431354.

[40] Kartavtsev YPH, Lee JS. Analysis of nucleotide diversity at genes Cyt-b and Co-1 on population, species, and genera levels. Applicability of DNA and allozyme data in the genetics of speciation. Genetika. 2006; 42: 437-461.

[41] Ryan JRJ, Esa YB. Phylogenetic analysis of Hampala Fishes (Subfamily Cyprininae) in malaysia inferred from partial mitochondrial cytochrome b dna sequences. Zoological Science. 2006; 23(10): 893-901.

[42] Tsigenopoulos CS, Kasapidis P, Berrebi P. Phylogenetic relationships of hexaploid large-sized barbs (genus Labeobarbus, Cyprinidae) based on mtDNA data. Mol Phylo Evol. 2010; 56: 851-856.

[43] Kartavtsev YPH, Batischeva N M, Bogutskaya NG, Katugina AO, Hanzawa N. Molecular systematics and DNA barcoding of Altai osmans, oreoleuciscus (pisces, Cyprinidae, and Leuciscinae), and their nearest relatives, inferred from sequences of cytochrome b (Cyt-b), cytochrome oxidase c (Co-1), and complete mitochondrial genome. Mitochondrial DNA Part A. 2016; 28: 502-517.

[44] Kvist L. Phylogeni and Phylogeography of European Parids. [Disertation]. Finland. Department of Biologi. OULU University. 2000

[45] Brown TA. Genome. 2nd edition. Wiley-Liss. Oxford. 2002.

[46] Weiss M, Goker M. Molecular Phylogenetic Reconstruction. The Yeasts, a Taxonomic Study. 2011; 11: 159-174.

[47] Cailliet GM, Love MS, Ebeling AW. Fishes: A field and laboratory manual on their structure, identification and natural history. Waveland Press, Inc., Long Grove, IL. 1986.

[48] Burland TG. DNA STAR's lasergene sequence analysis software. Methods Mol Biol. 2000; 132: 71-91.

[49] Rozas J, Sanchez-DelBarrio JC, Messeguer X, Rozas R. DnaSP, DNA Polymorphism Analyses by the Coalescent and Other Methods. Bioinformatics. 2003; 19: 2496-2497.

[50] Tamura K, Stecher G, Peterson D, Filipski A, Kumar S. MEGA 6: Molecular Evolutionary Genetics Analysis Version 6.0. Mol Biol Evol. 2013; 30: 2725-2729.

[51] Nei M and S. Kumar. Mol Evol Phyl. Oxford University Press. New York. 2000.

[52] Singh NS, Behera BK, Sharma AP. Population structure of Puntius sophore inferred from variation in mitochondrial DNA sequences. International Journal of Research in Fisheries and Aquaculture. 2013; 3(3):112115. 
[53] Pasi KS, Lakra WS, Bhatt JP, Goswami1 M, Malakar. Population structure of Tor tor inferred from mitochondrial gene cytochrome b. Mitochondrial DNA. 2013; 24(3): 290-296.

[54] Garg RK, Mishra V. Molecular insights into the genetic and haplotype diversity among four populations of Catla catla from Madhya Pradesh revealed through mtDNA cytochrome b gene sequences. JGEB. 2018; 16: 169-174.

[55] Melek O, Nazmi P. Determination of genetic structure in Barbus tauricus Kessler, 1877 populations inhabiting a few streams along the Black Sea Region (Turkey) inferred from mtDNA cytochrome b gene sequence analysis. EgeJFAS. 2019; 36(1): 1-11.

[56] Kartavtsev YPH. Divergences at Cyt-b and Co-1 mtDNA genes on different taxonomic levels and genetics of speciation in animals. Mitochondrial DNA. 2011; 22(3): 55-56.

[57] Witte K.-E, J Schmidt. Betta brownorum, a new species of anabantoids (Teleostei: Belontiidae) from northwestern Borneo, with a key to the genus. Ichthyological Exploration of Freshwaters. 1992; 2: 305-330.

[58] Gregory TR. Understanding Evolutionary Trees. Evo Edu Outreach. 2008; 1: 121-137.

[59] Song Z, Song J, Yue B. Population genetic diversity of Prenant's schizothoracin, Schizothorax prenanti, inferred from the mitochondrial DNA control region. Environ Biol Fish. 2008; 81: 247-252.

[60] Song J, Hou F, Zhang X, Yue B, Song Z. Mitochondrial genetic diversity and population structure of a vulnerable freshwater fish, rock carp (Procypris rabaudi) in upper Yangtze River drainage. Biochemical Systematics and Ecology. 2014; 55: 1-9. 